\title{
PRESIDENTIAL ADDRESS ONE VIEW OF THE FUTURE
}

\section{WARWICK CATTO \\ Ballance Agri-Nutrients Ltd, Private Bag 12503, Tauranga wcatto@ballance.co.nz}

I would firstly like to acknowledge the many members, presenters, organisers and executive members who have given there time and valuable input over the last 75 years making the NZ Grasslands Association the organisation it is today. The 68 proceedings are an invaluable record of NZ's post 1920s pastoral history and developments. It provides a scientific record with all its insights but also a time capsule of issues of the day and farm practices.

The relevance and future of the NZGA will depend on its members but its role as an extension vehicle and also as a publishing forum will continue. In 1980 the association had 870 members and today we have continued to hold this above 1000 members, $50 \%$ of whom are farmers. The membership and organisational history was well covered by R. Green in last year's 2005 Presidential address and is not repeated here.

Otago is an ideal place to hold the 75th anniversary Grassland Conference and some background on pastoral research is covered in other papers. Some historical highlights include the 1871 Mosgiel Woollen Mill, the 1879 establishment of the Kempthorne and Prosser superphosphate works at Burnside, the 1882 first frozen export shipments of lamb and dairy products from Port Chalmers and also the development of the co-operative dairy model.

The last 5 years have been relatively buoyant across the primary sector, a major shift from the 1980s when I first trained at Lincoln and entered the primary sector workforce in somewhat depressing times. It has taken almost 20 years for the primary and wider political sector to recover from the policy views of agriculture initially espoused in the early 1980 s which were reinforced by the pre 1987 sharemarket boom. Agriculture, forestry and horticultural exports have almost doubled from 1990 to the present from $\$ 10$ B to $\$ 20$ B and constitute $65 \%$ of NZ's total export revenue.

Only now are we starting to see nationally a resurgence in understanding of the importance of our farming sector and recognition that it is an innovative and growing sector. This "sunset industry" has continued to demonstrate significant productivity gains and increase its contribution to NZ's GDP. Also importantly, there are positive signs towards recognising the significant contribution the science sector provides to agriculture and redressing some of the negative science management processes that impact on these people. We can only wait to see how well the science sector is resourced to continue to deliver on creating our future opportunities.

Agricultural research from 1926 to 2001 has contributed a $17 \%$ annual return on the investment made (Hall \& Scobie 2006). This is a key endorsement to the relevance, value and adoption pathways of research generated in NZ. However, the rate of adoption/implementation of our innovations needs to continue to improve and serious thought and investment will be required in the areas of extension and adoption. So, as we look forward, there are some distinct challenges globally and domestically. These are primarily around energy, the environment and maintaining a competitive global advantage.

As described in the dairy and meat and wool industry strategies, we need to continue to improve on-farm productivity with targets typically set at about $4 \%$ pa. By necessity some of that gain must come from continued intensification of our farm systems. Whilst doing so, the dairy industry strategy describes a future challenge for a research farm to be able to achieve a $50 \%$ decrease in $\mathrm{N}$ and $\mathrm{P}$ losses (relative to a benchmarked farm). Challenges arise as to how we can deliver these and will be a combination of fertilisers, pastures, animals and management. However, the biggest challenge will be mitigating the increased losses from this intensification. I believe that increased focus on identifying and managing critical source areas (hot spots) will be crucial to achieving it economically. Also major pressures will only grow in regard to delivering stable or improved water quality. Our biggest challenge is finding a way that fosters adoption by farmers without 
Figure 1 Net global warming potential per tonne of P for SSP and TSP + elemental super and lime.

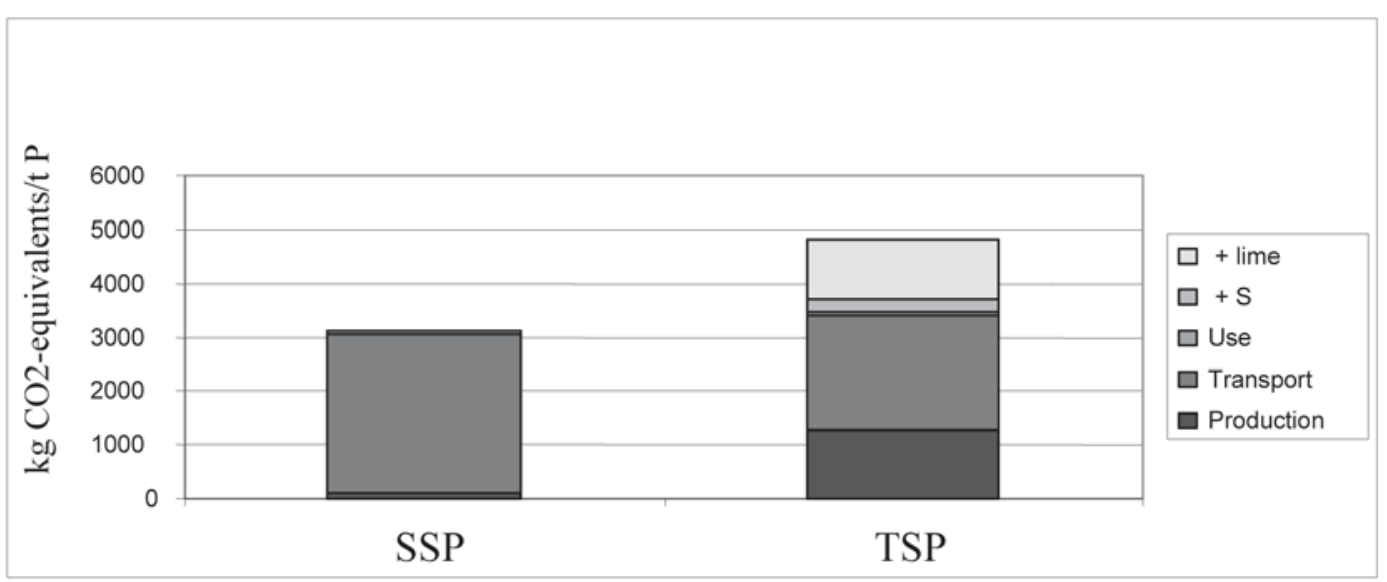

Figure 2 Energy consumption on a NZ Dairy Farm (S. Ledgard, C. Basset-Mens, M. Boyes, 2006 unpublished).

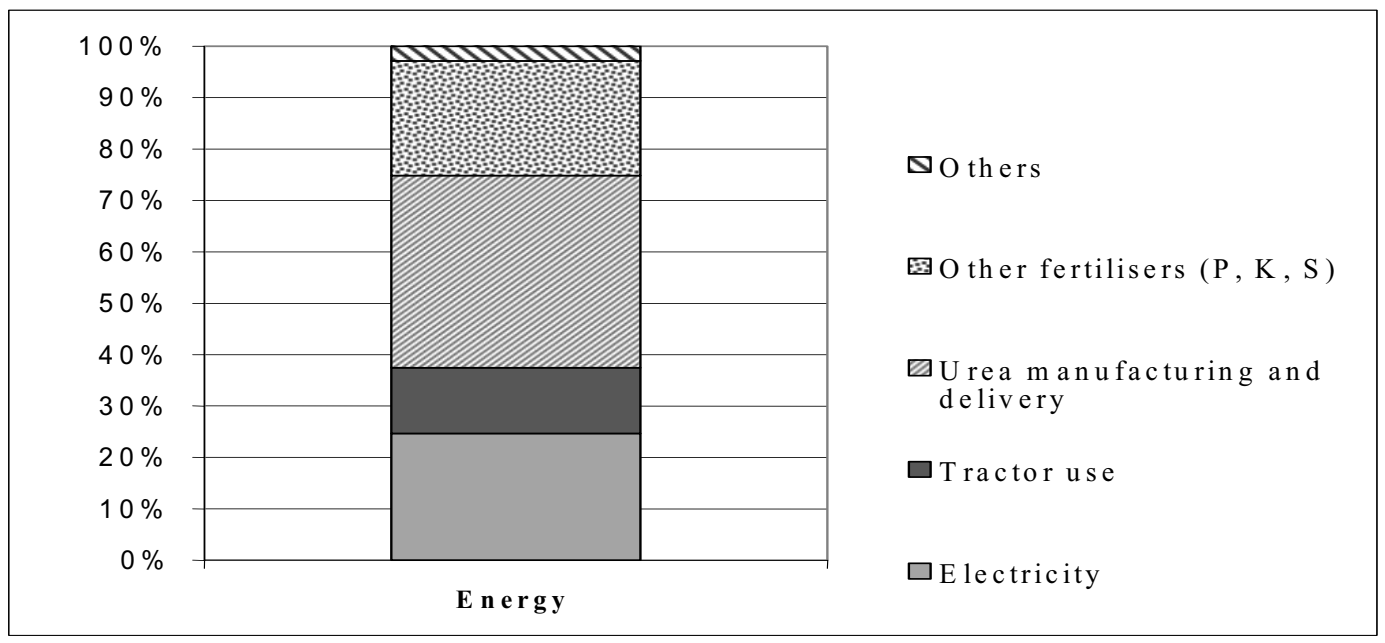

moving to a regulated input environment. The absence of economic drivers is currently a hindrance to adoption.

Nutrient supply is also likely to face a challenge in terms of raw material supply, cost and energy supply. The NZ fertiliser industry has been based on superphosphate but the ability to manufacture will depend on being able to continue to source competitively priced unprocessed rock that is suitable for domestic manufacture from a contaminants and odour perspective. The manufacture of superphosphate is an exothermic process i.e. there is an excess of energy from its production (which at most sites is used for electricity generation). This is an advantage over other sources of phosphate currently available (Fig. 1). With global energy demand continuing to grow the cost of energy and hence the price of nitrogenous fertilisers will increase and so we must strategically continue to focus research on clover/legume development to leverage the economic advantage $\mathrm{N}$ fixation can confer. As an example the contribution of nitrogen fertiliser use to energy consumption on a dairy farm typically consuming $100 \mathrm{~kg} \mathrm{~N} / \mathrm{ha}$ is $33 \%$ (Fig. 2). The energy consumption associated with $\mathrm{N}$ use is of particular relevance with the emergence of the concept of "Food Miles" in our European markets. We need to continue the development of pasture systems and clover varieties that mitigate our increasing dependence on fertiliser nitrogen.

\section{Energy - a Key Driver of the Future}

Energy cost and source will be a key driver of our 
Figure 3 Impact of $\mathrm{N}$-fertiliser use on oilseed rape crop biomass and additional energy fixing (rapeseed field trials (Yara, Germany 2006).

\section{GJ/ ha}

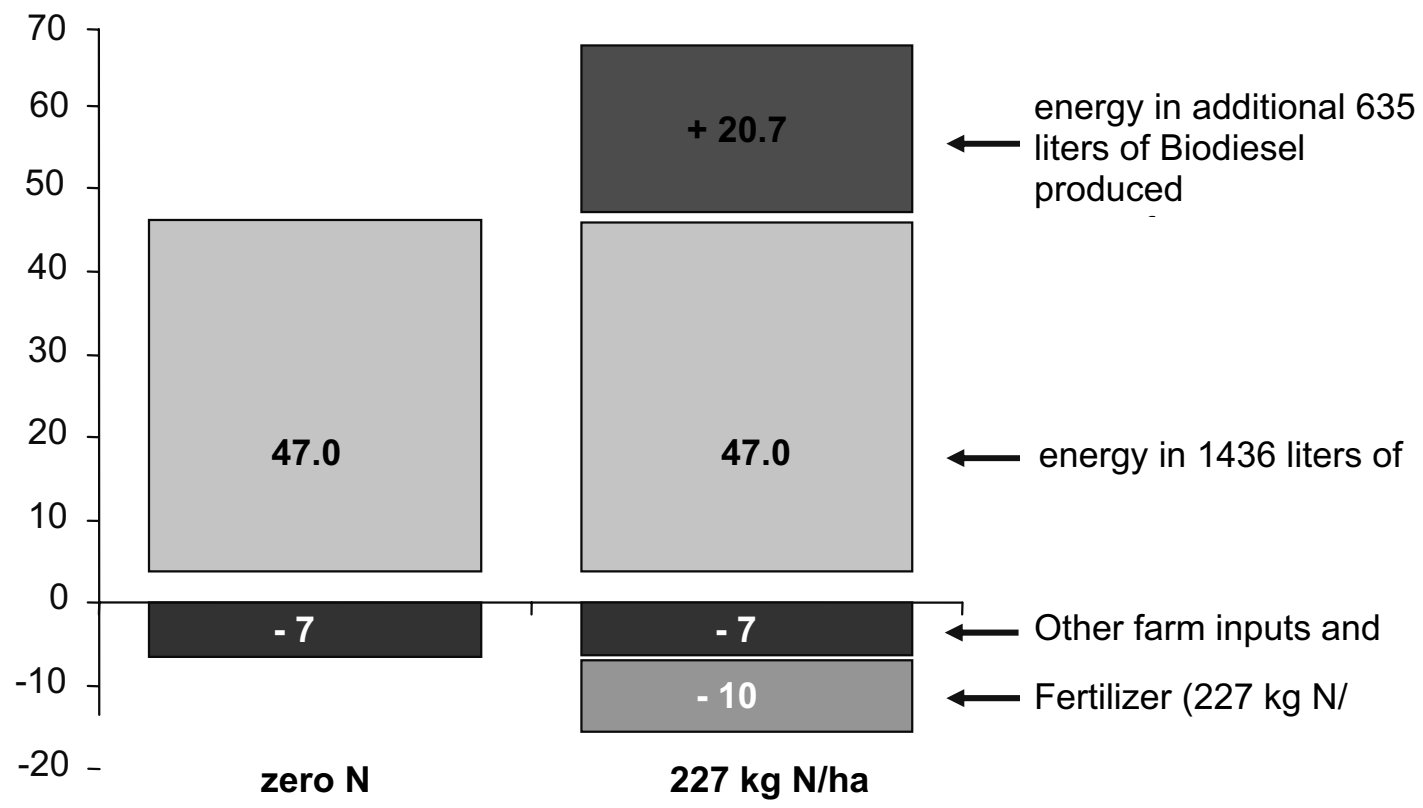

$\begin{array}{lr}3.78 & 5.45 \\ 1436 & 2071 \\ 47.0 & 677\end{array}$

agricultural future in NZ because of the potential worldwide diversion of land to biofuel production. Biofuels are not new to the southern region with the potential growing of sugar beet in South Otago explored in the late 1960s and the commercial production of rapeseed derived biodiesel from the Southoil (Southland Phosphate) oilseed extraction plant at Awarua in the early 1980 s.

Ethanol production derived from starch and sugar crops such as sugar cane, maize and cereals, expanded by $53 \%$ from 30 billion litres in 2000 to about 46 billion litres in 2005 . It is expected that world ethanol consumption will reach 54 billion litres by 2010 accounting for about $1 \%$ of world oil consumption. Note in the EU, biofuel is dominated by biodiesel from vegetable oils (FAO Food Outlook June 2006.)

The biggest concern is the potential impact of bioenergy on land resources. With the EU having a target of increasing the share of biofuels in transport to $8 \%$ these concerns are real. Estimates by OECD are that the EU would need to convert $70 \%$ of agricultural land to provide

\author{
Rapeseed yield (t/ha) \\ Biodiesel (I/ha) \\ Energy in Biodiesel (GJ/ha)
}

$10 \%$ of its energy need, whilst the United States, Brazil, and Canada would require 30,3 , and 0.3 percent of agricultural land respectively.

Hungary is reported to be planning to convert 1 $\mathrm{M}$ ha of farmland to biofuel production. So our future agricultural world is now closely linked in an input way to the future of crude oil. Figure 3 illustrates the net energy output of rapeseed plus the multiplying effect $\mathrm{N}$ use has in terms of energy output from rapeseed.

\section{Future Foods}

The real opportunity for NZ is not in commodities but in the continued quantification of the healthiness of food we currently produce and in optimising the nutritional value of our foods not only through plant and animal breeding but also fertiliser practices. Some current examples that illustrate the type of concept for functional foods include the provision of $\mathrm{A} 2$ milk and selenium fortified grains. But these concepts can easily be envisaged for meats and foods with, for example, mineral fortification, Omega 3 content, meat tenderness/flavour, and milk composition 
profiles. It is this ability to further refine, enhance and quantify the properties of our produce that will be essential for retaining our premium position in many markets and competitiveness, as our "low cost pasture" advantage is lost. These phytosanitary and health attributes are the future differentiators that discerning consumers will want and where we must be.

It is critical that NZ continues to invest in many of these areas now as the outputs, both in physical and intellectual property terms, are important for maintaining our standard of living in the future.

Finally I would like to conclude with some extracts from the first NZGA conference in 1931. Many of these brief abstracts illustrate a reference point as to where our knowledge has advanced from. But equally, many insights espoused remain the same today and by looking back on some historic work it helps put context around assumptions and understanding to our current systems. Its also provides some insight as to why we established a legume based pasture system rather than a nitrogen driven European system.

\section{A.Y. Montgomery "The Use of Nitrogen Fertilisers on Pastures in NZ"}

"the disadvantages of being 12,000 miles from our chief export market lies in the fact that our climate allows our growing of protein-rich fodder in every month in the year"

The role of $\mathrm{N}$ fertilisers was to "supply protein rich milk and flesh producing grass just at a time when it is needed most in winter and early spring"

An interesting observation counter to our current thinking was this

"an investigation by Levy and others at Dept. of Agriculture and DSIR showed a serious "feed flavour" occurs owing to pastures containing too high a percentage of clovers. This trouble can be overcome by use of sulphate of ammonia or other nitrogen fertiliser to produce a grass dominant sward"

T. Rigg and H.O. Askew "Mineral content of pastures investigation at the Cawthron Institute" "On bush sick soils the amount of iron provided by stock is probably much lower"

So it was envisaged that something was missing from our soils with iron a candidate for the cause of bush sickness but in 1935 cobalt deficiency was found to be the cause of bush sickness. Interestingly enough the early development of aerial topdressing was actually to allow application of copper and cobalt to pasture land in the Hauraki Plains and King Country because the terrain was too rough to allow for land application.

F.L.C. Scrivener "Some chemical methods of determining the lime requirement of soils"

Scrivener describes a range of methods for determining lime requirements, including measuring the calcium carbonate content of soil but also a method measuring soil $\mathrm{pH}$. A key point he makes regarding using the $\mathrm{pH}$ measurement which is still relevant today, was that $\mathrm{pH}$ alone is not a reliable indication of lime response. He noted that lime gave varied responses but in some regions was of paramount importance which is probably due to what we now understand was molybdenum deficiency. So analytical methods for determining nutrient requirements have come a long way to today's armoury of tools and measures.

A.W. Hudson "On the use of fertilisers on grassland and the technique and scope of experimental work"

In 1929/30, 330,000 tonnes of fertiliser was used of which $60 \%$ was superphosphate and the balance mainly basic slag. Only $17 \%$ of sown grassland was "manured" and lime was used only on $2.1 \%$ of grassland.

Hudson also proposed 2000 observational experiments to rapidly obtain pasture response data that would otherwise take a lifetime. He based this on his experience from the success of a smaller set of experiments across Canterbury, which quickly revealed varying nutrient responses and was applied by farmers.

He also comments on a trial technique, developed at Marton Experimental farm, of using a lawn-mower to measure herbage, noting the key advantage of cost without sacrifice of accuracy for field measurements. Again this is an example of a simple but profound change in technique, which is widely used today.

Most science managers could easily be quoted today saying something like the following; "something like $6 \mathrm{~d}$ to $1 /$ - per 100 pound value of our grassland exports is spent on grassland research. Hudson comments that is a small amount compared with what is spent on other industries"

Connell on grazing management in dairying 
Connell comments on the frequency of grazing and pasture quality and how some farmers (using what we would described as rotational grazing) are seeing a $50 \%$ increase in farm production. The concept of grazing management techniques has been a major area of progress over the last 75 years.

In conclusion, former Governor General, Lord Bledisloe, is quoted as saying that just as the 18th century is associated with a progressive revolution of arable husbandry, and the 19th a similar leap forward in the livestock husbandry, so the 20th century is calculated to rank as a revolution in grassland husbandry.

I would like to think of the 21st century ahead of us as still refining and building on the advancements that have arisen in the past but that it will primarily be the century of ecological husbandry. That is, it will be a period over which we will develop sustainable food production systems that protect the environment. These systems will be more intensive than the ones today but the husbandry associated with them will include a range of mitigation and management practices and economic drivers that minimise our footprint and create a truly clean, green environment. The quantification of farm footprints will require a substantial research effort to make equitable, informed decisions and I believe the New Zealand Grassland Association has a role to play in providing a forum in realising that future.

\section{REFERENCES}

FAO Food Outlook, 2006. Global Market Analysis No1 June 2006

Hall, J.; Scobie, G.M. 2006. The role of R\&D in productivity growth: The case of agriculture in New Zealand: 1927 to 2001. NZ Treasury Working Paper 06/01

Kuesters, J. 2006. Energy efficiency of biofuels Yara field trial data. Hanninghof, Yara International. 